Vol. 1, No. 2, Juli - Desember 2017

\title{
eäureligia
}

\section{REAKTUALISASI PENDIDIKAN KARAKTER PESANTREN DI ERA GLOBALISASI}

\section{Muhammad Lutfi}

Program Pascasarjana Institut Agama Islam Nurul Jadid (PPs IAINJ)

\section{Info Artikel}

Sejarah Artikel:

Diterima Maret 2017

Disetujui Juni 2017

Dipublikasikan Juli 2017

Keywords:

Pendidikan Karakter;

Pesantren;

Globalisasi.

\section{Abstract}

The study aimed to determine (1) Learning Auditory Intellectually Repetition (AIR) model on student's problem solving abilities environmental material. (2) Expository model teaching on student's problem solving abilities environmental material. (3) The difference between AIR and expository teaching model on student's problem solving abilities and environmental material is better between the two. The population in this study were students of class XI-IPS SMA Negeri 2 Brebes. The samples taken at random sampling with XI-IPS 1 as an experimental class and XI-IPS 2 as a control class. The study design used was quasy experimental with posttest-only control design.

\footnotetext{
Alamat Korespondensi:

Gedung E Lantai 1 Fakultas Tarbiyah

PO. Box 1 Paiton Probolinggo, 67291

E-mail: edureligia@gmail.com
}

ISSN 2549-4821

E-ISSN 2579-5694 


\section{PENDAHULUAN}

Karakter merupakan aspek penting dari kualitas SDM karena kualitas karakter bangsa menentukan kemajuan suatu bangsa. Karakter yang berkualitas perlu dibentuk dan dibina sejak usia dini. Usia dini meru pakan masa kritis bagi pembentukan kara kter seseorang. Menurut Freud kegagalan penanaman kepribadian yang baik di usia dini ini akan membentuk pribadi yang ber masalah di masa dewasanya kelak. Kesuk sesan orang tua membimbing anaknya da lam mengatasi konflik kepribadian di usia dini sangat menentukan kesuksesan anak dalam kehidupan sosial di masa dewasanya kelak (Muslich Masnur, 2011: 35). Karakter santri-santri akan terbentuk dengan baik, jika dalam proses tumbuh kembang mereka mendapatkan cukup ruang untuk mengekspresikan diri secara leluasa. Era globalisasi juga menghadirkan wajah baru dalam interaksi social masyarakat modern. Di era ini terjadi kompetisi yang sangat ketat, baik secara individumaupun kelompok. Karena kompetisi tidak hanya terjadi antara kelompok yang sama-sama kuat, tetapi juga antara yang kuat dan yang lemah. Pergerakan informasi yang cepat dan kompetisi yang ketat ini menjadi tantangan tersendiri bagi pesantren. Pesantren sebagai institusi pencetak pemimpin masa depan dan pusat pemberdaya masyarakat harus mampu mencetak generasi yang memiliki sumber daya yang mapan yang dapat bersaing ketat dalam pentas global. Oleh karena itu, pesantren harus dapat menghadapi era globalisasi yang pada awalnya merupakan tantangan dan rintangan menjadi peluang emas bagi embangunan masyarakat Indonesia. Tentunya, pesantren harus berproses dan berubah sesuai dengan kebutuhan masyarakat global dengan tidak meninggalkan tradisi lama yang masih dianggap baik (Islam, 2017).

Saat ini pendidikan formal di sekolah saja tidak cukup, pengaruh lingkungan dan kehidupan modern yang berkembang mem buat orangtua dan guru harus lebih waspada terhadap hal-hal negatif yang bisa merasuki pikiran anak. Agar anakanak penerus gen erasi menjadi anak yang baik, sholeh dan berhasil dalam kehidupan masyarakat bukan hanya dibutuhkan kepandaian dan ilmu yang tinggi, tetapi juga harus diimbangi dengan pembentukan karakter (Kurnia, 2010:96). Beberapa peneliti dan tokoh dunia juga banyak memberi pernyataan tentang pentingnya pendidikan karakter. Diantaranya Theodore Roosevelt, mantan Presiden USA yang mengatakan: "To educate a person in mind and not in morals is to educate a menace to so ciety" (mendidik seseorang dalam aspek kecerdasan otak dan bukan aspek moral adalah ancaman mara bahaya kepada masyarakat). Selain itu Mahatma Ghandi juga memperingatkan tentang salah satu dari tujuh dosa fatal yaitu "education without character" (pendidikan tanpa karakter) (Kurnia, 2010:96).

Situasi sosial, kultural masyarakat akhir-akhir ini memang sangat mengkhawatirkan. Ada berbagai macam peristiwa dalam pendidikan yang semakin merendahnya harkat dan derajat manusia. Hancurnya nilai-nilai moral, merebaknya ketidakadilan, tipisnya rasa solidaritas, telah terjadi dalam lembaga pendidikan (Syarnubi, 2013).

Pendidikan karakter menjadi semakin mendesak untuk diterapkan dalam lembaga pendidikan kita mengingat berbagai macam perilaku yang non-edukatif kini telah menyerembah dalam lembaga pendidikan kita, seperti fenomena kekerasan, pelecehan seksual, korupsi dan kesewenang-wenangan yang terjadi di kalangan sekolah. Gencarnya arus global tanpa disertai adanya filter dari masyarakat Indonesia, mengakibatkan rakyat mudah terbawa arus kebebasan dan indivudualisme, yang berdampak langsung terhadap menurunnya kualitas moral bangsa. Adanya penurunan kualitas moral bangsa saat ini, dicirikan dengan maraknya praktek Korupsi, Kolusi, dan Nepotisme (KKN), terjadinya konflik (antar etnis, agama, politis, remaja), meningkatnya kriminalitas, menurunnya etos kerja, dan sebagainya (Megawangi, 2004: 14). Lebih dari pada itu, krisis moral ini pun melanda generasi muda di persekolahan, hasil penelitian Megawangi tentang ketidakjujuran siswa Sekolah Menengah Kejuruan-Teknik Informatika (SMKTI) di Bogor, dimana hampir $81 \%$ siswanya sering membohongi orang tua $30,6 \%$ sering memalsukan tanda tangan orang tua/wali, $13 \%$ siswa sering mencuri dan $11 \%$ siswa sering memalak (Sri Wahyuni, 2013: 2).

Pondok Pesantren merupakan sebuah lembaga pendidikan yang berada pada lingkungan masyarakat Indonesia dengan model pembinaan yang sarat dengan pendidikan luhur bangsa. Sehingga pesantren menjadi sebuah lembaga yang sangat efektif dalam pengembangan pendidikan karakter (akhlak) peserta didik. Seperti ungkapan untuk mengubah karakter yang 
Pesantren sudah terpa dibandingkan dengan pendidikan karakter di persekolahan" (Sauri, 2011). Di tidak hanya mengembangkan kemampuan kognitif, akan tetapi aspek afektif dan psikomotorik siswa Pondok pesantren sebagai salah satu jenis lembaga pendidikan Islam Indonesia, berbagai aspek, watak religius, sehingga lahirlah output pesantren yang memiliki pengetahuan dan akhlak karimah karakter santri karena pendidikan pesantren siswa diasramakan di pondok dalam pemimpin pesantren dan suasana religius dalam pembelajaran di pesantren. Di kungan masyarakat Indonesia dengan model pembinaan yang sarat dengan pendidikan nilai, baik nilai agama maupun nilai-nilai luhur bangsa. Sehingga pesantren menjadi sebuah lembaga yang sangat efektif dalam pengembangan pendidikan karakter (akhlak) peserta didik. Seperti ungkapan Sauri yang menyatakan bahwa "pendidikan karakter di Pesantren lebih efektif dibandingkan dengan pendidikan karakter di persekolahan" (Sauri, 2011).

Di Pesantren, model pembinaan pembelajaran yang dilaksanakan bersifat kholistik, tidak hanya mengembangkan kemampuan kognitif, akan tetapi aspek afektif dan psikomotorik siswa terasah dengan optimal. Pondok pesantren sebagai salah satu jenis lembaga pendidikan Islam di Indonesia, telah terbukti secara empiris mampu mengembangkan santri dari berbagai aspek, meliputi kemampuan intelektual, emosional dan pembentukan watak religius, sehingga lahirlah output pesantren yang memiliki pengetahuan dan akhlak karimah atau berkarakter. Keberhasilan pesantren dalam membentuk karakter santri karena pendidikan pesantren siswa diasramakan di pondok dalam bimbingan dan pengawasan kiyai, adanya wibawa dan keteladanan kiyai sebagai pemimpin pesantren dan suasana religius dalam pembelajaran di pesantren. Di samping itu, proses pendidikan pesantren lebih menekankan pada aspek aqidah, ibadah dan akhlak karimah dengan pendekatan pendidikannya yang khas, seperti ukhuwah, ketaatan, keteladanan, kesederhanaan, kemandirian, kebebasan, keikhlasan, dan pluralitas (Dawam, 1995:9).

\section{PENDIDIKAN \\ KARAKTER \\ DI PESANTREN}

\section{Pendidikan Karakter}

Secara etimologis, kata karakter (Inggris: character) berasal dari bahasa Yunani (Greek), yaitu eharassein yang berarti "to engrave". (Kevin \& Karen, 1999:5) Kata "to engrave" itu sendiri dapat diterjemahkan menjadi mengukir, melukis, memahati kan, atau menggoreskan.

Dalam bahasa Inggris, karakter disebut dengan istilah character yang berarti mengukir, melukis, memahatkan, atau menggoreskan. (Kevin \& Karen, 1999: 5) Berbeda dengan kamus bahasa Inggris, Kamus Bahasa Indonesia mengartikan kata "karakter" dengan tabiat, sifat-sifat kejiwaan, akhlak atau budi pekerti yang membedakan seseorang dengan yang lain. Merujuk pada pengertian kebahasaan dalam kamus bahasa Indonesia tersebut, karakter dapat dipahami sebagai huruf, angka, ruang, simbol khusus yang dapat dimunculkan pada layar dengan papan ketik (Pusat Bahasa Departemen Pendidikan Nasional, 2008: 682). Artinya, orang berkarakter adalah orang yang berkepribadian, berperilaku, bersifat, bertabiat, atau berwatak. Di samping karakter dapat dimaknai secara etimologis, karakter juga dapat dimaknai secara terminologis. Secara terminologis Thomas Lickona, sebagaimana dikutip Marzuki mendevinisikan karakter sebagai "A reliable inner disposition to respond to situations in a morally good way." Selanjutnya, Lickona menyatakan, "Character so conceived has three interrelated parts: moral knowing; moral feeling, and moral behavior". Karakter mulia (good character) mencakup pengetahuan tentang kebaikan (moral knowing) yang menimbulkan komitmen terhadap kebaikan (moral feeling), dan akhirnya benar-benar melakukan kebaikan (moral behavior). Dengan demikian, karakter mengacu pada serangkaian pengetahuan (cognitives) sikap (attitudes), dan, motivasi s(motivations), serta perilaku (behaviors) dan keterampilan (Marzuki, 2011: 470).

Simon Philips mengartikan karakter adalah kumpulan tata nilai yang menuju pada suatu sistem, yang melandasi pemikiran, sikap, dan perilaku yang ditampilkan (Simon Philips, 2008:235). Sedangkan Doni Koesoema memahami bahwa karakter sama dengan kepribadian. Kepribadian dianggap sebagai "ciri, atau karakteristik, atau gaya, atau sifat khas dari diri seseorang yang bersumber dari bentukanbentukan yang diterima dari lingkungan, misalnya lingkungan keluarga pada masa kecil dan juga bawaan seseorang sejak lahir." (Doeni Koesoema, 2007: 98). 
William Berkovitz memberi definisi karakter sebagai serangkaian ciri-ciri psikologis individu yang mempengaruhi kemampuan pribadi dan kecendrungan berfungsi secara moral (William Damon, 2002: 45). Definisi karakter menurut Pritchard adalah sesuatu yang berkaitan dengan kebiasaan hidup individu yang bersifat menetap dan cenderung positif (I Pritchard, 1988: 467).

Karakter itu berkaitan dengan kekuatan moral, berkonotasi 'positif', bukan netral. Jadi, 'orang berkarakter' adalah orang yang mempunyai kualitas moral (tertentu) positif (Muali, 2016). Dengan demikian, pendidikan membangun karakter, secara implisit mengandung arti membangun sifat atau pola perilaku yang didasari atau berkaitan dengan dimensi moral yang positif atau baik, bukan yang negative atau buruk. Hal ini didukung oleh Peterson dan Seligman yang mengaitkan secara langsung 'character strength' dengan kebajikan. Character strength dipandang sebagai unsur-unsur psikologis yang membangun kebajikan (virtues) (Raka, 2007: 5). Salah satu kriteria utama dari 'character strength' adalah bahwa karakter tersebut berkontribusi besar dalam mewujudkan sepenuhnya potensi dan cita-cita seseorang dalam membangun kehidupan yang baik, yang bermanfaat bagi dirinya, orang lain, dan bangsanya. Menurut Foerster ada empat ciri dasar karakter (Departemen Pendidikan, 2010).

1. Keteraturan interior di mana setiap tindakan diukur berdasar hierarki nilai. Nilai menjadi pedoman normatif setiap tindakan.

2. Koherensi yang memberi keberanian, membuat seseorang teguh pada prinsip, tidak mudah terombangambing pada situasi baru atau takut risiko. Koherensi merupakan dasar yang membangun rasa percaya satu sama lain. Tidak adanya koherensi meruntuhkan kredibilitas seseorang.

3. Otonomi. Di situ seseorang menginternalisasikan aturan dari luar sampai menjadi nilai-nilai bagi pribadi. Ini dapat dilihat lewat penilaian atas keputusan pribadi tanpa terpengaruh atau desakan pihak lain.

4. Keteguhan dan kesetiaan. Keteguhan merupakan daya tahan seseorang guna mengingini apa yang dipandang baik. Dan kesetiaan merupakan dasar bagi penghormatan atas komitmen yang dipilih.

Kematangan keempat karakter ini, lanjut Foerster, memungkinkan manusia melewati tahap individualitas menuju personalitas. "Orang-orang modern sering mencampuradukkan antara individualitas dan personalitas, antara aku alami dan aku rohani, antara independensi eksterior dan interior". Karakter inilah yang menentukan forma seorang pribadi dalam segala tindakannya.

Istilah pendidikan karakter mulai dikenalkan sejak tahun 1900-an. Thomas Lickona disebutsebut sebagai pengusungnya, terutama ketika ia menulis buku yang berjudul The Return of Character Education dan kemudian disusul buku berikutnya, yakni Educating for Character. How Our School Can Teach Respect and Responsibility. Melalui buku-buku Thomas Lickona tersebut, dunia Barat menyadari betapa pentingnya pendidikan karakter.

Menurut Lickona, pendidikan karakter mencakup tiga unsur pokok, yaitu mengetahui kebaikan (knowing the good), mencintai kebaikan (desiring the good), dan melakukan kebaikan (doing the good). Senada dengan Lickona, Frye mendefinisikan pendidikan karakter sebagai, "A national movement creating schools that foster ethical, responsible, and caring young people by modeling and teaching good character through an emphasis on universal values that we all share"(Mike, 2002: 2). Dengan demikian, pendidikan karakter dapat diartikan sebagai upaya sadar dan terencana dalam mengetahui kebenaran atau kebaikan, mencintainya dan melakukannya dalam kehidupan sehari-hari.

Berbeda dengan Frye, Dono Baswardono menyatakan bahwa nilai-nilai karakter ada dua macam, yakni nilai-nilai karakter inti dan nilainilai karakter turunan. Nila-nilai karakter inti bersifat universal dan berlaku sepanjang zaman tanpa ada perubahan, sedangkan nilai-nilai turunan karakter sifatnya lebih fleksibel sesuai dengan kontek budaya lokal. Sekadar contoh, sifat jujur adalah sifat baik yang tetap berlaku sepanjang zaman. Dalam praktiknya, nilai kejujuran dapat berubah-ubah. Salah satu contohnya adalah "anti korupsi". Sikap ini merupakan keturunan karakter jujur. Jadi, nilai inti karakter adalah kejujuran itu sendiri, bukan pada "anti korupsi".

Tim Sprod mengetengahkan peranan guru dan metode membangun suatu kelas sebagai suatu masyarakat untuk melakukan inkuiri etis (Tim Sprod, 2001: vii). Guru merupakan sosok sentral dalam pendidikan karakter. Baik atau buruknya pendidikan sangat tergantung pada sosok yang satu ini. Guru tidak hanya menjadi 
pengajar, namun juga sebagai pendidik, pembimbing, pelatih, penasihat, pembaharu, model dan teladan, pibadi, pendorong kreativitas, pembangkit pandangan, researcher, dan sederetan tugas mulia lainnya (Mulyasa, 2005: 3764).

Dalam konteks pendidikan karakter, peran guru sangat vital sebagai sosok yang diidolakan, serta menjadi sumber inspirasi dan motivasi murid-muridnya. Sikap dan perilaku seorang guru sangat membekas dalam diri seorang murid, sehingga ucapan, karakter, dan kepribadian guru menjadi cermin.

\section{Pesantren}

Pondok pesantren merupakan lembaga pendidikan Islam tertua yang berfungsi sebagai salah satu benteng pertahanan umat Islam, pusat dakwah dan pusat pengembangan masyarakat muslim Indonesia. Istilah pondok pesantren pertama kali dikenal di Jawa, di Aceh dikenal rangkah dan dayah, di Sumatera Barat dengan surau (Putra: 2001: 47).

Soegarda Poerbakawatja, menjelaskan bahwa pesantren berasal dari kata santri, yaitu seorang yang belajar agama Islam, sehingga pesantren dapat diartikan sebagai tempat orang berkumpul untuk belajar agama Islam (Soegarda, 1976: 223). Manfred Ziemek menyebutkan, bahwa asal etimologi dari pesantren adalah pe-santria-an, "tempat santri". Santri atau murid (umumnya sangat berbeda-beda) mendapat pelajaran dari pimpinan pesantren (kyai) dan oleh para guru (ulama atau ustadz). Pelajarannya mencakup berbagai bidang tentang pengetahuan Islam (Munafred, 1985: 16). Selanjutnya, Karel A. Steenbrink, berpendapat bahwa pesantren adalah sekolah tradisional Islam berasrama di Indonesia. Institusi pengajaran ini memfokuskan pada pengajaran agama dengan menggunakan metode pengajaran tradisional dan mempunyai aturan-aturan, administrasi, dan kurikulum pengajaran yang khan. Pesantren biasanya dipimpin oleh seorang guru agama atau ulama yang sekaligus sebagai pengajar santri (Karel, 1994: 13).

\section{POLA PENDIDKAN KARAKTER DI PESANTREN}

Pondok pesantren adalah sebuah sistem yang unik. Tidak hanya unik dalam pendekatan pembelajarannya, tetapi juga unik dalam pandangan hidup dan tata nilai yang dianut, cara hidup yang ditempuh, struktur pembagian kewenangan, dan semua aspek-aspek kependidikan dan kemasyarakatan lainnya. Oleh sebab itu, tidak ada definisi yang dapat secara tepat mewakili seluruh pondok pesantren yang ada. Masing-masing pondok mempunyai keistimewaan sendiri, yang bisa jadi tidak dimiliki oleh yang lain. Meskipun demikian, dalam hal-hal tertentu pondok pesantren memiliki persamaan. Persamaan persamaan inilah yang lazim disebut sebagai ciri pondok pesantren, dan selama ini dianggap dapat mengimplikasi pondok pesantren secara kelembagaan.

Sebuah lembaga pendidikan dapat disebut sebagai pondok pesantren apabila di dalamnya terdapat sedikitnya lima unsur, yaitu: kiyai, santri, pengajian, asrama, masjid dengan segala aktivitas pendidikan keagamaan dan kemasyarakatannya.

Persamaan lain yang terdapat pada pondok pesantren adalah bahwa semua pondok pesantren melaksanakan tiga fungsi kegiatan yang dikenal dengan Tri Darma Pondok Pesantren, yaitu:

1. Peningkatan keimanan dan ketakwaan terhadap Allah SWT

2. Pengembangan keilmuan yang bermanfaat

3. Pengabdian terhadap agama, masyarakat dan Negara.

Selain model pembelajaran aspek kelembagaan dan aspek fungsi kegiatan di atas, pondok pesantren juga disatukan melalui persamaan atas hubungan yang khas dalam kependidikan dan kemasyarakatan, yaitu:

a. Hubungan yang dekat antara kiyai dengan santri, walaupun ada sebagian kecil pesantren yang santrinya takut kepada kyai karena kyai tersebut sangat kharismatik.

b. Ketaatan santri yang tinggi kepada kiyai; walaupun ada sebagian kecil santri yang "bandel", terkadang mereka didepan kyai sangat hormat dan patuh tetapi saat kyai tidak ada dia menjahili teman-temannya.

c. Hidup hemat dan sederhana; keadaan pondok pesantren "memaksa" mereka untuk berhemat karena hidup seadanya, tidak disediakan fasilitas lebih walaupun dia berasal dari keluarga yang kaya.

d. Tingginya semangat kemandirian pada santri; hidup jauh dari orang tua membuat santri terdidik mandiri, semua dilakukan sendiri.

e. Berkembangnya suasana persaudaraan dan tolong menolong; hidup di sebuah pesantren telah menciptakan rasa persaudaraan yang 
erat pada santri, karena teman sekamar adalah orang yang paling dekat yang bisa saling membantu jika terjadi masalah.

f. Kuatnya semangat mencapai citacita; tiap santri yang masuk ke pesantren mempunyai motto hidup masing-masing, sehingga motto hidup tersebut bisa dijadikan semangat mereka untuk mencapai yang yang mereka inginkan.

g. Tertanamnya sikap disiplin dan istiqomah; disiplin bisa terbentuk karena kebiasaan, kebiasaan yang baik dibentuk di sebuah pondok pesantren agar santrisantrinya hidup disiplin.

Keragaman dan keunikan pondok pesantren juga terdapat pada sistem pembelajarannya. Hal ini terkait dengan kenyataan, sejauh mana sebuah pondok pesantren tetap mempertahankan sistem pembelajaran lama yang cenderung menggunakan pendekatan individual atau kelompok, dan sejauh mana pondok pesantren menyerap sistem pendidikan modern yang lebih mengedepankan pendekatan klasikal.

\section{TANTANGAN DI ERA GLOBALISASI}

Di arus zaman yang sudah modern ini, tantangan semakin besar. Manusia tidak lagi harus keluar rumah untuk melakukan kejahatan, tapi cukup diteras rumah, atau di kmaar, kejahatan besar bisa dilakukan. Ini merupakan tantangan untuk bisa ditanggulangi.

Pendidikan karakter sejak dini sangat diperlukan agar nantinya akan terbiasa dengan perbuatan-perbuatan yang bertanggung jawab.

Tidak menutup kemungkinan, pesantren diera globalisasi ini juga semakin menjadi incaran bagi pelaku kejahatan. Para santri yang dulu bisa tenang belajar, diskusi dan yang lainya, kini menjadin incaran para pelaku kejahatan. Para pelaku kejahatan sudah berani masuk ke ranah pesantren untuk mempengaruhi para santri untuk melakukan hal-hal kejahatan dengan iming-iming kenikmatan dan kesenangan yang daris ebelumnya tidak pernah dirasakan di pesantren.

Selain itu, tidak sedikit para lulusan pesantren yang sudah keluar dari pesantren meras terbebas dari segala aturan yang membuatnya lepas control sampai melakukan kejahatan-kejahatan yang tidak sewajarnya. Mereka merasa dirinya telah bebas dari aturan ketat pesantren dan cenderung arogan.

Oeh karena itu, perlu adanya penanaman kembali karakter kepesantrenan yang benarbenar menjiwai terhadap para santri sejak dini. Ini penting untuk menjaga pribadi santri yang santun dan baik. Pembentukan karakter ini harus benar-benar menjadi prioritas untuk menjaga para santri dan bangsa pada umumnya dari kerusakan-kerusakan moral dan kejahatankejahatan yang tidak bertanggung jawab.

\section{PENUTUP}

Karakter santri-santri akan terbentuk dengan baik, jika dalam proses tumbuh kembang mereka mendapatkan cukup ruang untuk mengekspresikan diri secara leluasa. Pendidikan karakter di pesantren perlu dioptimalkan kembali mengingatnya banyaknya para pelaku kejahatan yang mulai masuk ke dalam dunia pesantren.

Pesantren harus sigap dan waspada menghadapi kenyataan ini. Tantangan para santri di era global ini semakin berat karena harus dihadapkan dengan teknologi yang sangat mudah diakses. Sehingga pengaruh jelak dari dunai luar pesantren sangat mudah masuk.

Pesantren penting memperkenalkan dasar-dasar rasional dan logis kepada peserta didik agar mereka terhindar dari meniru yang tidak didasarkan pertimbangan rasional dan pengetahuan. Metode Kisah keteladanan merupakan salah satu upaya untuk mendidik murid agar mengambil pelajaran dari kejadian di masa lampau. Apabila kejadian tersebut merupakan kejadian yang baik, maka harus diikutinya, sebaliknya apabila kejadian tersebut kejadian yang bertentangan dengan agama Islam maka harus dihindari.

Penanaman karakter pada para santri perlu dioptimalkan untuk menjaga generasi dari perbuatan-perbuatan yang anmoral.

\section{DAFTAR PUSTAKA}

Mulyasa. 2005. Menjadi Guru Professional; Menciptakan Pembelajaran Kreatif dan Menyenangkan. Bandung: Rosda.

I Pritchard. 1988. Character Educatioan: Research Prospects and Problem. American Journal of Education.

Islam, S. (2017). Karakteristik Pendidikan Karakter; Menjawab Tantangan Multidimensional Melalui Implementasi Kurikulum 2013, 1(1), 89-101. 
Koesoema, Doeni. 2007. Pendidikan Karakter. Strategi Mendidik Anak Di Zaman Global. Jakarta: Grasindo.

Marzuki. 2011. Prinsip Dasar Akhlak Mulia: Pengantar Studi Konsep-Konsep Dasar Etiha dalam Islam. Yogyakarta: Debut Wahana Press-FISE UNY.

Masnur, Muslich. 2011. Pendidikan Karakter Menjawab Tantangan Krisis Multidimensional. Jakarta: Bumi Aksara.

Megawangi, R. 2004. Pendidikan Karakter solusi yang Tepat untuk Membangun Bangsa. Bandung: BP migas dan Energi.

Muali, C. (2016). Konstruksi Strategi Pembelajaran Berbasis Multiple Intelligences Sebagai Upaya Pemecahan Masalah Belajar. Jurnal Pedagogik, 3(2), 1-11

Philips, Simon. 2008. Refleksi Karakter Bangsa. Jakarta

Pusat Bahasa Departemen Pendidikan Nasional. 2008. Kamus Bahasa Indonesia. Cet. I. Jakarta: Pusat Bahasa.

Puspita, Kurnia. 2002. Pendidikan Karakter dalam Film Upin Ipin Episode 1-18. Yogayakarta: UIN Sunan Kalijaga. Tesis. Qomar.

Raka Gede at.all. 2007. Pendidikan Karakter di Sekolah; Dari Gagasan Ke Tindakan. Jakarta: Elex Media Komputindo.

Ryan, Kevin \& Karen E. Bohlin. 1999. Building Character in Schools: Practical Ways to Bring Moral Instruction to Life. San Francisco: Jossey Bass.

Sauri, S. Pendidikan Pesantren dalam Pendidikan Karakter.

Sprod, Tim. 2001. Philoshophical Discussion in Moral Education. London: Routledge.

Tanshzil, Sri Wahyuni. Model Pembinaan Pendidikan Karakter pada Lingkungan Pondok Pesantren

Syarnubi, 2013. Nilai-nilai Pendidikan Karakter dalam Pemikiran M. Quraish Shihab: Studi atas Tafsir AlMisbah, Yogyakarta: UIN Sunan Kalijaga. 